\title{
IN PATIENTS WITH DIABETIC FOOT SYNDROME
}

SURGICAL DEPARTMENT №2, BOGOMOLETS NATIONAL MEDICAL UNIVERSITY, Kyiv, Ukraine D.M.PhD. Borys G. Bezrodny, M.D.Maksym O. Prystupiuk

\section{INTRODUCTION}

DIABETIC FOOT SYNDROME IS A COMMON SURGICAL PATHOLOGY. IT IS THE MAIN CAUSE OF LOWER LIMB AMPUTATIONS, WHICH CAN BE AVOIDED IN 85\% OF CASES BY ACTIVE DETECTION AND LONG-TERM COMPENSATION OF T2DM, TIMELY DIAGNOSTICS OF PERIPHERAL NEUROPATHY.

\section{PURPOSE}

To STUdY RELATION BETWEen COMPENSATION OF DIABETES (by HbA1C) AND TIME NEEDED FOR HEALING OF ULCERS AND PURULENT PROCESSES IN PATIENTS WITH NEUROISCHEMIC FORMS OF DIABETIC FOOT.

\section{RESULTS}

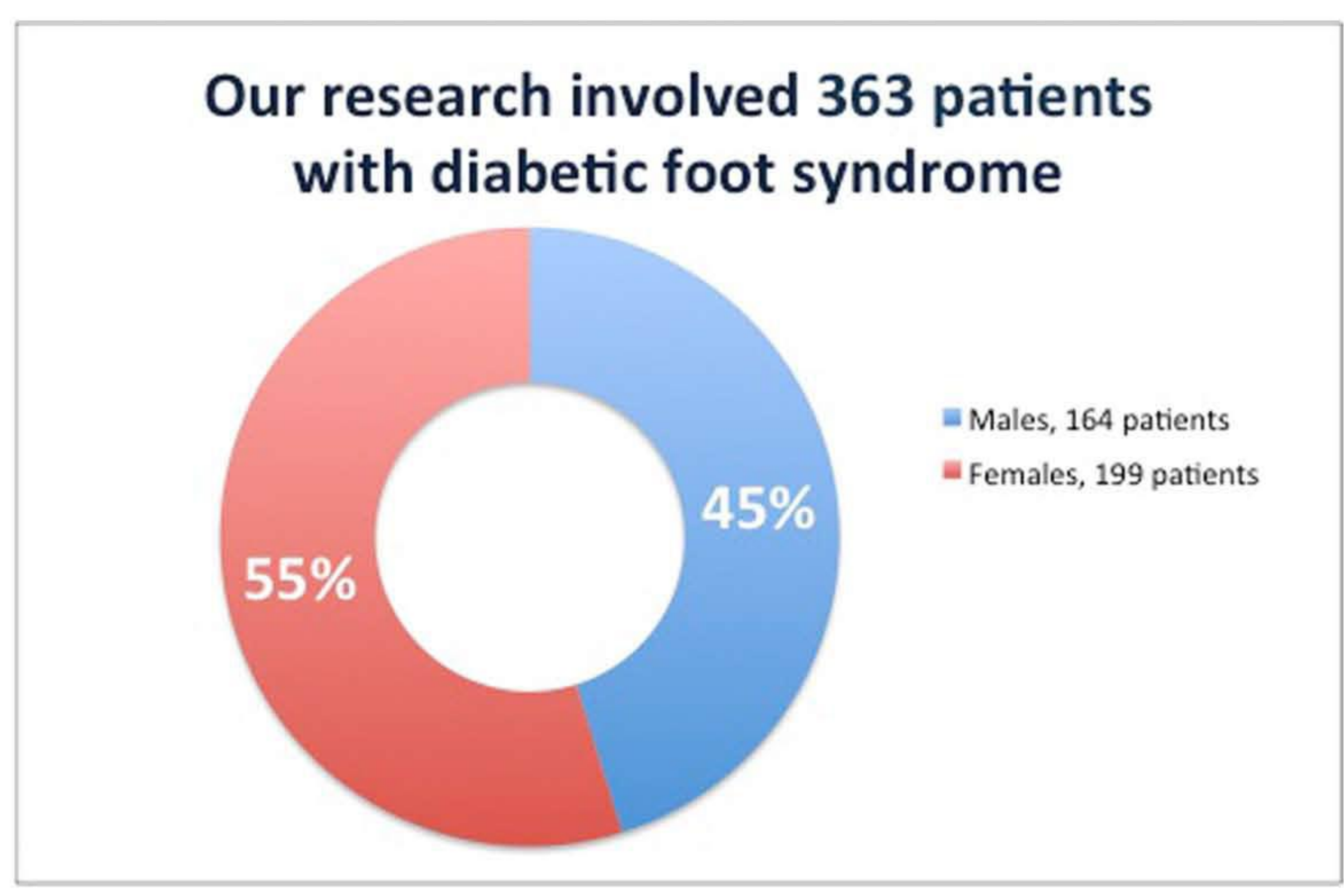

\begin{tabular}{|c|c|c|}
\hline \multicolumn{3}{|c|}{$\begin{array}{l}\text { Duration of Treatment of N Neuroischemicic Formus of Diabetic Foot } \\
\text { According to HhbAic level }\end{array}$} \\
\hline HbAlclevels $\quad$ Cender & Males & Females \\
\hline HbA1c level 15.5 $1.0 \%$ & $34.66 \pm 0.40$ days & $31.42 \pm 1.18$ days \\
\hline 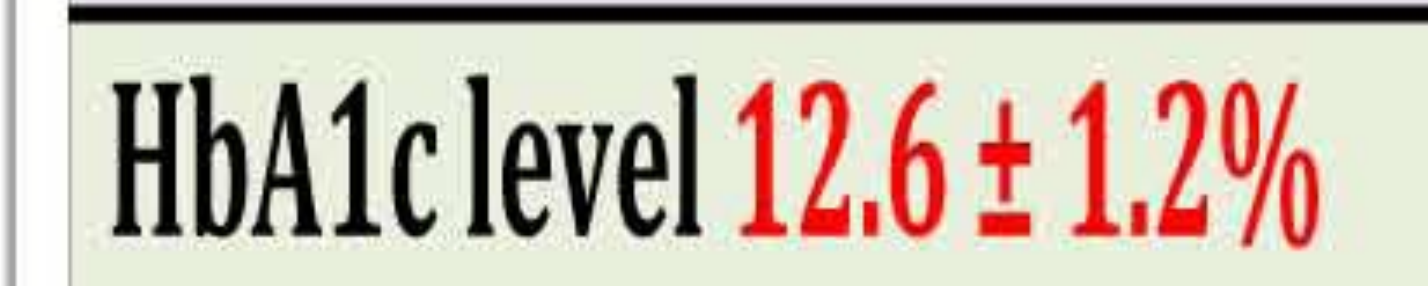 & $16.60 \pm 0.26$ days & $18.95 \pm 0.51$ days \\
\hline
\end{tabular}

THE RESULTS OF TREATMENT OF 363 PATIENTS WERE WORKED OUT:

164 MALES (45\%) AND 199 Females (55\%),

THE AVERAGE AGE OF MEN $65 \pm 0.20$ YeARS, WOMEN $-70 \pm 0.22$ YeARS

$(P<0.001)$. BY ADMISSION, PATIENTS HAD BEEN TREATED BY ORAL HYPOGLYCEMIC MEDICINES IN COMBINATIONS OF UP TO THREE DRUGS AT THE TIME WITH MAXIMUM PERMISSIBLE DOSES. IN HOSPTTAL ALL SUBJECTS WERE TREATED WITH INSULIN.

THE MOST COMMON SURGERY WAS OPENING OF ABSCESSES AND PHLEGMONS IN $40 \%$ OF MALES AND $60 \%$ OF FEMALES. AMPUTATIONS OF LOWER LIMBS AND PHALANGES WERE PERFORMED IN 40\%

OF MEN (OVER 66 YeARS) AND 20\% OF WOMEN (OVER 70 YearS).

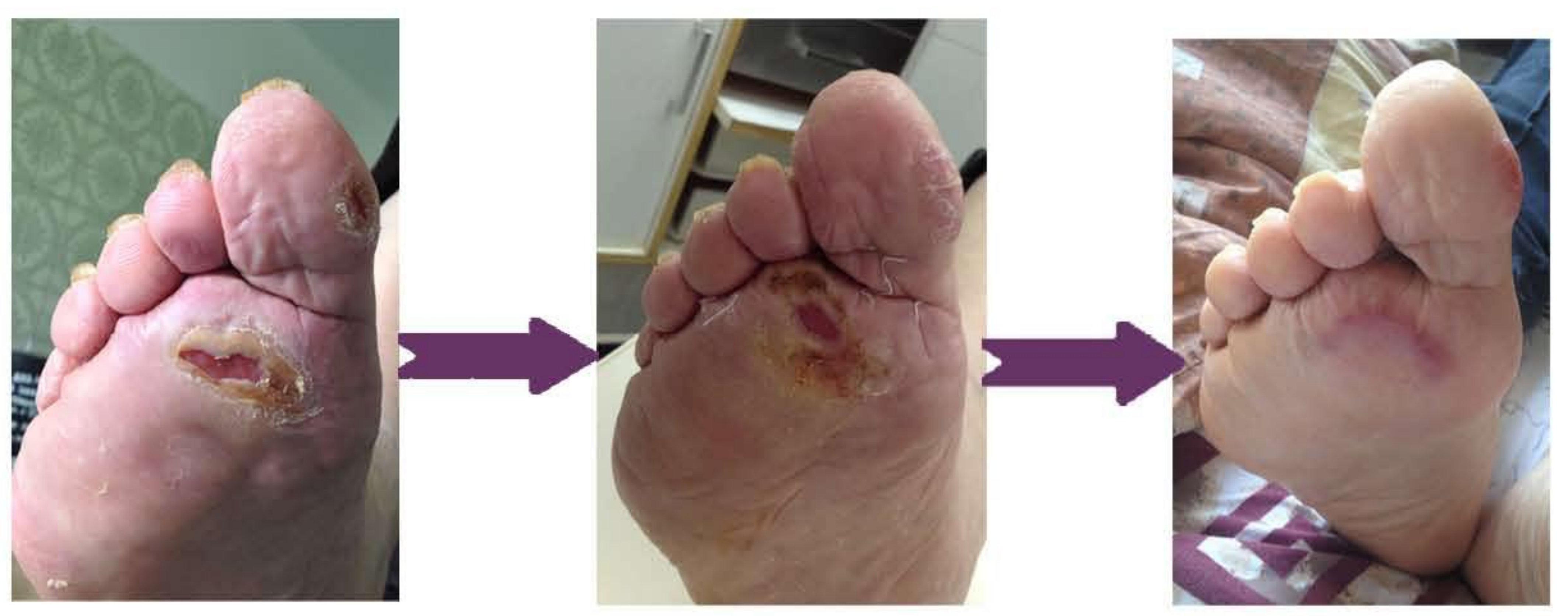

IN TERMS OF POST-PRANDIAL GLYCEMIA, COMPENSATION OF

DIABETES WAS ACHIEVED IN $22 \%$ OF MALES AND $32 \%$ OF FEMALES,

STAY PERIOD IN HOSPITAL OF WHOM WAS THE LOWEST.

\section{CONCLUSIONS}

1. WiTH HBA1C $15,5 \pm 1,0 \%$, DURATION OF TREATMENT OF NEUROISCHEMIC FORMS OF DIABETIC FOOT LASTED $34.66 \pm 0.40$ DAYS FOR MALES AND $31.42 \pm 1.18$ dAYS FOR FEMALES, WHILE WITH HBA1C $12.6 \pm 1.2 \%$ it LASTED $16.60 \pm 0.26$ AND $18.95 \pm 0.51$ DAYS RESPECTIVELY.

2. FASTING GLYCEMIA UP TO 6 MMOL/L AND POST-PRANDIAL GLYCEMIA UP TO $10 \mathrm{MmOL/L}$ ARE THE BEST VALUES FOR ENHANCING REPARATIVE PROCESSES IN PATIENTS AND SHORTENING THEIR HOSPITAL STAY.

3. AMONG PATIENTS WITH UNCOMPENSATED DIABETES, NUMBER OF LIMB AMPUTATIONS IS SO HIGHT THAT THIS SHOULD MOtIVATE PATIENTS FOR CONDUCTING ADEQUATE TREATMENT AND SELF-CONTROL OF DIABETES.

16-20 May 2015. Dublin, Ireland. The 17th European Congress of Endocrinology

\section{3-EP}

